\title{
Article
}

\section{Meeting EU ELV targets: Pilot-scale pyrolysis automotive shredder residue investigation of PAHs, PCBs and environmental contaminants in the solid residue products}

\author{
Williams, Karl S and Khodier, Ala \\ Available at http://clok.uclan.ac.uk/32021/ \\ Williams, Karl S ORCID: 0000-0003-2250-3488 and Khodier, Ala (2020) \\ Meeting EU ELV targets: Pilot-scale pyrolysis automotive shredder residue \\ investigation of PAHs, PCBs and environmental contaminants in the solid \\ residue products. Waste Management, 105 . pp. 233-239. ISSN 0956-053X
}

It is advisable to refer to the publisher's version if you intend to cite from the work. http://dx.doi.org/10.1016/j.wasman.2020.02.005

For more information about UCLan's research in this area go to

http://www.uclan.ac.uk/researchgroups/ and search for <name of research Group>.

For information about Research generally at UCLan please go to http://www.uclan.ac.uk/research/

All outputs in CLoK are protected by Intellectual Property Rights law, including Copyright law. Copyright, IPR and Moral Rights for the works on this site are retained by the individual authors and/or other copyright owners. Terms and conditions for use of this material are defined in the policies page. 


\title{
Meeting EU ELV targets: Pilot-scale pyrolysis automotive shredder residue investigation of PAHs, PCBs and environmental contaminants in the solid residue products
}

\author{
Karl S. Williams ${ }^{\text {a, }}$, Ala Khodier ${ }^{\text {a, b }}$ \\ ${ }^{a}$ Centre for Waste Management, University of Central Lancashire, Preston, PR1 2HE, UK \\ e-mail: kswilliams@uclan.ac.uk, akhodier2@uclan.ac.uk \\ ${ }^{b}$ Recycling Lives Recycling Park, Preston, Lancashire, PR2 5BX, UK \\ e-mail: ala.khodier@recyclinglives.com
}

Abstract

The EU's publication of the 2017 End-of-Life Vehicle Recycling and Recovery results reported that the UK failed to meet its targets. The Commission's data showed that the UK only achieved a rate of $94.1 \%$ falling short of the $95 \%$ target. The treatment of automotive shredder residue (ASR) using pyrolysis technologies offers a potential solution to this shortfall. The pyrolysis products could contribute to the target as well as supporting the circular economy package. However, there are questions about their hazardous nature and whether they qualify as secondary products. ASR, from a commercial plant, was processed through a pilot-scale pyrolysis unit, which separated the char into two fractions: coarse $\geq 0.1$ $\mathrm{mm}$ and fine $\leq 0.1 \mathrm{~mm}$. These were chosen as potential commercial products. Chars were produced from two processing temperatures of 800 and $1000^{\circ} \mathrm{C}$. These temperatures maximise gas production and produce the best "quality" char in terms of limiting organic contamination. It was found that the toxicity of the chars changed with both processing temperature and size fraction; with the maximum total PAHs concentration in the fine fraction at $800^{\circ} \mathrm{C}$. The coarse fractions were shown to be non-hazardous. It is suggested that some form of post-separation may be required to remove the hazardous component. The implication was that non-separated char could be classified as hazardous even if its overall characteristics were not, due to the role of dilution. If there were any questions about the status of the char this could prevent the use of ASR to meet the higher ELV target. 
34 Keywords: Automotive shredder residue; Pyrolysis; Char; PAHs analysis; PCBs analysis; waste acceptance criteria

\section{Introduction}

Once the End-of-Life Vehicle (ELV) has been depolluted and dismantled it is shredded for metals recovery. The unrecoverable material is designated automotive shredder residue (ASR) and is destined for landfilling. The ASR consists of a complex mixture of organic materials such as foams, plastics, rubber, fibres, textiles as well as inorganic materials like glasses, metals and inerts (Cossu and Lai, 2015). The ASR fraction may be up to $25 \%$ of the initial ELV's mass. In order to meet the ELV Directive of 95\% post-shredder processing is required. The final composition of ASR may vary depending on the post-shredder technologies employed at different shredder sites. Typical differences are based on the use of eddy current separators to remove non-ferrous metal (wires) or trommels and sink float separation for the recovery of polymers (Vermeulen et al., 2011). It is anticipated that in the future, the amount of ASR will increase due to car manufacturing changes to light weighting and new material usage (polymer substitution), (Davies, 2012; Alonso et al., 2007). Other changes to vehicles are the increase in electronic components units and change from combustion fuel to electric batteries or fuel cells. This will result in the presence of high value resources like gold and rare earth metals (Cucchiella et al., 2016; Restrepo et al., 2017) but also brings its own challenges to attempts to meet the ELV directive target. The European ELV Directive (EC, 2000) and the recently adopted Circular Economy Action Plan (EC, 2019) are forcing the shredding operators to recover 95\%wt of a vehicle and achieve zero waste to landfill. Already in 2017, the UK failed to meet the higher target by only achieving $94.1 \%$ (Eurostat ELV 2019). In order to meet these challenges, it will be necessary to consider thermal treatment of ASR through either gasification or pyrolysis 
(Cossu and Lai, 2015; Ruffino, 2014). Currently, there are no commercial plants that offer a

60 feasible method for the thermal recovery of ASR (Khodier et al., 2018). For example, at present the Ebara plant in Japan (Cossu et al., 2014) mixes sewage sludge in a 70/30 ratio (Selinger et al., 2003) but this falls short of the Circular Economy Action Plan. Pyrolysis is defined as the thermal degradation of materials in the absence of oxygen at operating temperatures above $300^{\circ} \mathrm{C}$. The products of this process are a char (solid residue), condensable organic vapours (condense to a dark brown viscous liquid known as pyrolytic liquids) and gases (non-condensable organics). Depending on the final temperature, pyrolysis will yield mainly char at low temperature $\left(\leq 450^{\circ} \mathrm{C}\right)$, mainly liquids/oil at moderate temperature $\left(450-700^{\circ} \mathrm{C}\right)$ and mainly gases at high temperature $\left(\geq 800^{\circ} \mathrm{C}\right)$. Char is primarily composed of carbon (carbon content varies as the pyrolysis temperature changes (Williams, 2005; Tchobanoglous et al., 1993), low nitrogen and hydrogen contents, metals and other inert materials, which is why it has been seen as a fuel or as an inert additive (Fortuna et al., 1997). Char has a high nutrient retention capacity, high surface area and high water retention capacity and therefore may be applied as a strong soil modifier. The use of the char in this way would assist in meeting the ELV Directive target. However, further studies are necessary to identify whether the char produced from a specific feedstock/material is environmentally inert to be deposited on land or landfilled. There are legislative restrictions to protect the flora and fauna from pollutant up-take to unacceptable levels. For example, polycyclic aromatic hydrocarbons (PAHs) are included in the European Union (EC, 2004) and US Environmental Protection Agency (USDHHS, 1995) list as priority pollutants. PAHs represent the largest group of compounds that are mutagenic, carcinogenic and teratogenic (GFEA, 2012). Other examples which are considered environmental pollutants are polychlorinated biphenyls (PCBs) which are mixtures of up to 209 individual chlorinated compounds, of which 113 are known to be present in the environment and are classified as persistent organic pollutants and may have mutagenic properties (GFEA, 2012; Pascal, 2005). 
There have been numerous studies over the years on ASR pyrolysis (;Santini et al., 2012; Haydary et al., 2016; Mayyas et al., 2016; Notarnicola et al., 2017; Anzano et al., 2017) which have focused on the product yields based on lab-scale trials ( $\left.\mathrm{mg-g} \mathrm{hr}{ }^{-1}\right)$. In contrast the characterisation and the use of pyrolysis products, (the char), have received less attention. Also, Vermeulen et al. (2011), Harder and Forton (2007) and Cossu et al. (2014) in their comprehensive review concluded that there was very limited use of ASR pilot-scale pyrolysis experiments. This means that sampling errors from lab-scale experiments potentially play a significant role in the outcome analysis of the ASR products. A notable attempt at addressing the shortfall of lab-based testing was carried out by Day et al. (1996) who used a commercial screw kiln unit. This had a continuous feed of $200 \mathrm{~kg} \mathrm{hr}^{-1}$ of ASR and corresponded to a residence time of $15 \mathrm{~min}$ at $500^{\circ} \mathrm{C}$. The chemical composition of the gas, liquid and solid fractions were all determined. The residual char was discharged from the reactor into a catch pot fitted with a screen separator to produce two size fractions: a fine portion $(<0.12 \mathrm{~mm})$ and a coarse portion $(>0.12 \mathrm{~mm})$. Day et al (1996) only carried out heavy metal concentrations and leachability tests on both char portions. Elemental analysis was performed and although heavy metals concentrations were relatively high (zinc, lead and copper in both fine and coarse char fractions), these were not detected in the leachability tests. As they did not investigate the amounts of organic pollutants in the fractions, they could not determine the hazardous or non-hazardous nature of the fractions. Galvagno et al. (2001) used a pilot-scale rotary kiln $\left(5-7 \mathrm{~kg} \mathrm{hr}^{-1}\right)$, with a residence time up to $40 \mathrm{~min}$. They used varying process temperatures $\left(550,600,680^{\circ} \mathrm{C}\right)$. Galvagno et al. (2001) carried out similar analysis to Day et al. (1996) with comparable results. Khodier et al. (2017) used a continuous feed of $10 \mathrm{~kg} \mathrm{hr}^{-1}$ of ASR with a residence time of $15 \mathrm{~min}$ at two temperatures of 800 and $1000^{\circ} \mathrm{C}$. They investigated the characteristics of the char produced from a separator to two size fractions (fine $<0.10 \mathrm{~mm}$ and coarse $>0.10 \mathrm{~mm}$ ). The results revealed that the higher calorific value was in the fine fractions and therefore had a high economic value. The coarse 
111 fraction had a high ash content, iron, silica, aluminium, calcium and nickel. They concluded

112 that the segregation of char would assist in optimisation of energy and resource recovery.

113 However, they recommended that the levels of organic pollutant, such as PAHs, in the char

114 would potentially determine its processing and secondary use. Anzano et al. (2017) claim to

115 be one of the first to investigate the distribution of PAHs in the char produced from ASR

116 pyrolysis. They used lab-scale pyrolysis and did not detect any PAHs in the char produced at

$117500^{\circ} \mathrm{C}$, however, at $700^{\circ} \mathrm{C}$ the maximum total concentration of $19.41 \mathrm{ng} \mathrm{g}^{-1}$ was observed.

118 These results support further investigation of PAHs in the solid residue from larger-scale

119 ASR pyrolysis.

120 This study investigates the organic content of the solid residue from ASR pyrolysed in

121 a pilot-scale rotary kiln test rig at $10 \mathrm{~kg} \mathrm{hr}^{-1}$. Solid residue products were characterised for

122 PAHs concentration. Furthermore, unlike other studies in the literature, the concentrations of

123 PCBs, BTEX (benzene, toluene, ethylbenzene, xylenes), TOCs (total organic carbon) were

124 determined. In addition, the study measured all the parameters necessary for the waste

125 acceptance criteria (WAC) in the solid residue and thereby determined their potential

126 environmental impact.

127

128 2. Experimental methods

129

\subsection{The ASR feed material}

130 The ASR materials production, sample preparation and size reductions used in this series of

131 tests were reported previously (Khodier et al., 2018; Khodier et al., 2017). A total of $208 \mathrm{t}$ of

132 ASR was collected from a processing plant over four day period. This was cone and

133 quartered to produce a total sample of $800 \mathrm{~kg}$. This was processed through a $50 \mathrm{~mm}$ screen to

134 produce the final feedstock. Material compositions, physical and chemical characterisation

135 are presented in Table 1. 
137 Table 1. Characteristics of the ASR feed material used in the study.

\begin{tabular}{|c|c|c|c|c|c|c|}
\hline \multirow[t]{2}{*}{ Parameter } & \multirow[t]{2}{*}{ Unit } & \multirow[t]{2}{*}{ Results } & & \multicolumn{3}{|c|}{ Components } \\
\hline & & & & $\mathrm{mg} / \mathrm{kg}$ & & $\%$ wt \\
\hline Gross Calorific value & $\mathrm{kJ} / \mathrm{kg}$ & 16300 & Metals & & Materials & \\
\hline Proximate analysis ${ }^{a}$ & & & $\mathrm{Cu}$ & 7 & Plastic & 47.88 \\
\hline Moisture & $\%$ wt & 22 & $\mathrm{Hg}$ & $<1$ & Foam & 2.94 \\
\hline Ash & $\%$ wt & 20 & $\mathrm{Cd}$ & $<1$ & Rubber & 15.88 \\
\hline Volatile matter & $\%$ wt & 53 & $\mathrm{Tl}$ & $<1$ & Textile/fabric & 10.35 \\
\hline Fixed carbon & $\%$ wt & 5 & $\mathrm{Sb}$ & 12 & Cork & 11.05 \\
\hline Total & $\%$ wt & 100 & As & $<1$ & Wood & 1.17 \\
\hline Ultimate analysis & & & $\mathrm{Cr}$ & 16 & Wiring/electrical & 1.76 \\
\hline $\mathrm{C}$ & $\%$ wt & 38.46 & Co & $<1$ & Glass & 0.82 \\
\hline $\mathrm{H}$ & $\%$ wt & 3 & $\mathrm{~Pb}$ & 56 & Paper & 0.47 \\
\hline $\mathrm{N}$ & $\%$ wt & 2 & $\mathrm{Mn}$ & 24 & Cardboard & 0.23 \\
\hline $\mathrm{O}$ & $\%$ wt & 14 & $\mathrm{Ni}$ & 7 & Dirt & 0.35 \\
\hline S & $\%$ wt & 0.2 & Sn & $<1$ & Fines (e.g. soil) & 6.57 \\
\hline $\mathrm{Cl}$ & $\%$ wt & 0.3 & $\mathrm{~V}$ & $<1$ & Metals ${ }^{b}$ & 0.47 \\
\hline & & & & & Others & 0.06 \\
\hline
\end{tabular}

$138 \quad{ }^{\mathrm{a}} \mathrm{ASR}=$ as-received (AR) after shredding.

$139 \mathrm{~b}^{\mathrm{b}}$ fine metals caught into the soil/dirt, (hard to separate).

140

$141 \quad 2.2$ The pyrolysis process - char sample preparation

142 Pyrolysis experiments were performed in a pilot-scale rotary kiln at two temperatures of 800

143 and $1000^{\circ} \mathrm{C}$ with a constant ASR feed rate of $10 \mathrm{~kg} \mathrm{hr}^{-1}$ which corresponded to a residence

144 time of about $15 \mathrm{~min}$. The rotary kiln unit description, feeding system and heating procedure

145 has been explained previously (Khodier et al., 2017). The two temperatures were chosen to

146 maximise the production of gas and produce char with lowest amounts of residue organics.

147 By operating at the higher temperatures it would present char with a lower range of

148 contaminants than those from lower operating temperatures typically in the $500-700^{\circ} \mathrm{C}$. Two

149 char fractions were produced $>0.1 \mathrm{~mm}$ and $<0.1 \mathrm{~mm}$. The proximate split was $80: 20 \%$ wt

150 ratio coarse to fine fractions by weight. Fig. 1 shows the two fractions of residue, illustrating

151 the different physical nature of each one. Samples were collected after each test run, weighed

152 and stored prior to analysis. 


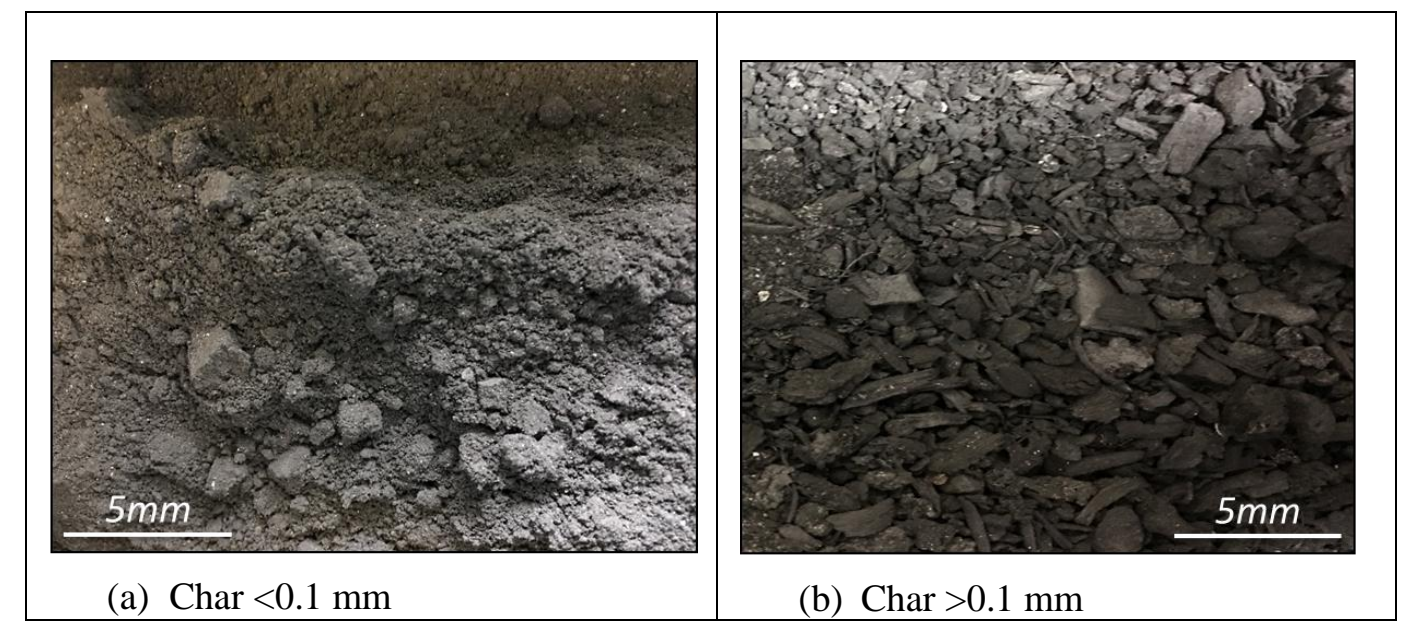

154 Fig. 1. Optical images of the pyrolysis char products.

\subsection{Pollutant/Environmental analysis of ASR and the solids residue}

158 The experimental methods used were statistically controlled using both process and

159 instrument quality control samples. These were sourced independently from the solutions

160 used to calibrate the analysis methodology. Instrument and process blank solutions were also

161 run at regular intervals (with each batch) to monitor potential sources of contamination.

162 All samples for the analysis were extracted from cone and quartered samples of the

163 ASR and pyrolysis solid residues. Ultrasonic-enhanced solvent extraction, based on the EPA

1643550 method (USEPA, 2007), was used to prepare samples. Anhydrous sodium sulphate was

165 added to a $5 \mathrm{~g}$ sample and extracted using ultrasonic extraction with a 50:50 mixture of

166 hexane/acetone. Agilent 7890 and 6890 gas chromatographs, in various configurations, were

167 used to detect PAH, PCB, TPH and BTX as shown in Table 2.

168

169 Table 2. Organic analysis operating conditions.

\begin{tabular}{|c|c|c|c|c|c|c|}
\hline nts & $\begin{array}{l}\text { Agilent } \\
\text { Instrument }\end{array}$ & $\begin{array}{l}\text { Injection } \\
\text { volume } \mu 1\end{array}$ & Detector & Column & Temperature Programme & $\begin{array}{l}\text { Carrier } \\
\text { Gas }\end{array}$ \\
\hline
\end{tabular}




\begin{tabular}{|c|c|c|c|c|c|c|}
\hline PAH & 7890 & 2.0 & GC/MS ${ }^{a}$ & DB-5ms & $\begin{array}{l}40^{\circ} \mathrm{C} \text { for } 1 \mathrm{~min} \text { to } 120^{\circ} \mathrm{C} \text { at } 25^{\circ} \mathrm{C} \\
\min ^{-1} \text {, then } 160^{\circ} \mathrm{C} \text { at } 10^{\circ} \mathrm{C} \min ^{-1} \\
\text { and finally to } 300^{\circ} \mathrm{C} \text { at } \\
5^{\circ} \mathrm{C} \text { min }^{-1} \text {, final hold time of } 15 \\
\text { min. }\end{array}$ & $\mathrm{He}$ \\
\hline PCB & 7890 & 2.0 & $\mathrm{GC} / \mathrm{ECD}^{\mathrm{b}}$ & HP-5ms & $\begin{array}{l}75^{\circ} \mathrm{C} \text { for } 3 \mathrm{~min}, \text { to } 150^{\circ} \mathrm{C} \text { at } 15^{\circ} \mathrm{C} \\
\min ^{-1} \text {, then to } 260^{\circ} \mathrm{C} \text { at } 6^{\circ} \mathrm{C} \mathrm{min}{ }^{-1}, \\
\text { finally to } 300^{\circ} \mathrm{C} \text { at } 20^{\circ} \mathrm{C} \mathrm{min}^{-1} \\
\text { rate held for } 5 \mathrm{~min}\end{array}$ & $\mathrm{~N}_{2}$ \\
\hline $\mathrm{TPH}$ & 6890 & 1.0 & GC/FID ${ }^{c}$ & DB-5ms & $\begin{array}{l}40^{\circ} \mathrm{C} \text { for } 1 \text { min to } 320^{\circ} \mathrm{C} \text { at } \\
10^{\circ} \mathrm{C} \mathrm{m^{-1 }} \text {, final hold of } 40 \\
\text { min. }\end{array}$ & $\mathrm{He}$ \\
\hline BTEX & 6890 & 1.0 & GC/FID & DB-642 & $\begin{array}{l}30^{\circ} \mathrm{C} \text { for } 1 \mathrm{~min} \text {, to } 100^{\circ} \mathrm{C} \text { at } 5^{\circ} \mathrm{C} \\
\min ^{-1} \text { to } 220^{\circ} \mathrm{C} \text { at } 8^{\circ} \mathrm{C} \min ^{-1}, \\
\text { final hold of } 5 \mathrm{~min} .\end{array}$ & $\mathrm{He}$ \\
\hline \multicolumn{7}{|c|}{$\begin{array}{l}\text { a GC/MS: gas chromatography equipped with high resolution mass spectrometry } \\
\text { b GC/ECD: gas chromatography equipped with electron capture detector }\end{array}$} \\
\hline
\end{tabular}

Samples for both TOC and LOI were prepared from air-dried and ground samples (5

$177 \mathrm{~g}$ ) that had been ground nominally to $212 \mu \mathrm{m}$. The ground samples were weighed and heated

178 in a furnace (Lenton Furnaces \& Ovens, Hope Valley, UK) to the required temperature. Total

179 organic carbon was analysed for both ASR and char based on the methods used by Heron et

180 al., (1997) and Schumacher, (2002). Samples were mixed with $10 \mathrm{ml}$ of concentrated

181 sulphuric acid. Total organic carbon content was determined using an ELTRA induction

182 furnace fitted with a nondispersive infrared (NDIR) cell (CS-800, ELTRA GmbH, Germany).

183 Loss on ignition was determined from samples in a furnace at $550^{\circ} \mathrm{C}$ for $2 \mathrm{hr}$. It was

184 then placed in a desiccator to cool for at least $60 \mathrm{~min}$. Loss on ignition was calculated from

185 the loss in mass of the sample.

187 Sample using BS 6068 standard (1986). A Jenway Model 3510 pH meter was used to

188 determine $\mathrm{pH}$ of original ASR and char samples. 


\section{Results and discussion}

\subsection{Organic contaminates/Environmental toxicity of ASR}

191 The results obtained from the organic analysis conducted on the ASR are presented in Table

192 3. The criteria used by landfill operators to distinguish inert waste, stable non-reactive waste

193 and non-hazardous waste (transposed from Council Decision annex 2003/33/EC (EC, 2002))

194 are shown in Table 4. It can be seen that the amount of oils and organic contaminants

195 detected in the ASR sample (Table 3) were within the limit values which apply to non-

196 hazardous waste acceptance criteria. Mancini et al. (2010) and Morselli et al. (2010) reported

197 higher amounts of mineral oils contents in the ASR obtained from the Italian shredder

198 industry of $22.3 \mathrm{~g} \mathrm{~kg}^{-1}$ and $26.8 \mathrm{~g} \mathrm{~kg}^{-1}$, respectively. This may be in part be explained by the

199 depollution and dismantling technologies applied to the ELVs prior to shredding and be

200 specific to national standards at shredder facilities. The concentrations of the PCB in our

201 study were similar to those reported by Santini et al. (2012) of $0.008 \mathrm{mg} \mathrm{kg}^{-1}$ value. Whereas,

202 Viotti et al. (2010), Morselli et al. (2010), Mancini et al. (2010) and Cossu, (2014) detected

203 higher PCBs concentrations of 2.97, 5.3, 7.9 and $44.45 \mathrm{mg} \mathrm{kg}^{-1}$, respectively. The outcome

204 from TOC, BTEX, LOI and PAHs analysis in the ASR were not reported in the literature for

205 comparison to this study's results.

206 Table 3. Organic analysis of the feed material (ASR).

\begin{tabular}{ll}
\hline Parameter & Result \\
\hline TOC $(\% \mathrm{w} / \mathrm{w})$ & 0.26 \\
LOI $(\% \mathrm{w} / \mathrm{w})$ & 1.39 \\
BTEX $\left(\mathrm{mg} \mathrm{kg}^{-1}\right)$ & $<0.01$ \\
PCBs $(7 \mathrm{Congeners})\left(\mathrm{mg} \mathrm{kg}^{-1}\right)$ & $<0.01$ \\
Mineral oil $(\mathrm{C} 10-\mathrm{C} 40)\left(\mathrm{mg} \mathrm{kg}^{-1}\right)$ & 7.7 \\
PAHs (Total Speciated) $\left(\mathrm{mg} \mathrm{kg}^{-1}\right)$ & 6.1 \\
pH & 7.20 \\
\hline
\end{tabular}

Table 4. Criteria for granular waste acceptable at landfills (Transposed from Council 
Decision annex 2003/33/EC (EC, 2002)).

\begin{tabular}{lccc}
\hline Parameter & $\begin{array}{l}\text { Inert waste } \\
\text { landfill }\end{array}$ & $\begin{array}{l}\text { Stable non-reactive / } \\
\text { non-hazardous }\end{array}$ & $\begin{array}{c}\text { Hazardous } \\
\text { waste landfill }\end{array}$ \\
\hline TOC $(\% \mathrm{w} / \mathrm{w})$ & 3 & 5 & $6^{*}$ \\
LOI $(\% \mathrm{w} / \mathrm{w})$ & $<10$ & $<10$ & $10^{*}$ \\
BTEX $\left(\mathrm{mg} \mathrm{kg}^{-1}\right)$ & 6 & & \\
PCBs $(7 \mathrm{Congeners})\left(\mathrm{mg} \mathrm{kg}^{-1}\right)$ & 1 & & \\
Mineral oil (C10-C40) $\left(\mathrm{mg} \mathrm{kg}^{-1}\right)$ & 500 & & \\
PAHs (Total Speciated) $\left(\mathrm{mg} \mathrm{kg}^{-1}\right)$ & 100 & $>6$ & \\
pH & &
\end{tabular}

Keys: * Either TOC or LOI must be used for hazardous wastes

\subsection{Organic contaminates of char residue}

213 The analysis of the residual char was performed on both the coarse and fine fractions. The

214 coarse materials showed undetectable levels of PAHs, PCBs, BTEXs and TPHs. This

215 supported previous findings of the inert nature of coarse char $(>0.1 \mathrm{~mm})$ (Khodier et al.,

216 2017). The PAHs' content in the fine chars samples are shown in Table 5. The maximum

217 total concentration of PAHs was detected in the char produced at $800^{\circ} \mathrm{C}$, with naphthalene

218 and phenanthrene being the most abundant compounds. Similar results for these compounds

219 were reported by Day et al. (1999) for ASR pyrolysis char produced at $750^{\circ} \mathrm{C}$. In contrast at

$2201000^{\circ} \mathrm{C}$, fluoranthene and pyrene were the most abundant compounds with concentration of

221879 and $1250 \mathrm{mg} \mathrm{kg}^{-1}$ respectively. The concentration of the total PAHs detected in our study

222 were higher than the values reported previously in the literature with typical values being:

223 1.2-100 mg kg${ }^{-1}$ (Buss et al., 2016); 1-19.41 $\mathrm{ng} \mathrm{kg}^{-1}$ (Anzano et al., 2017). This may be a

224 reflection that these studies were conducted in small lab-scale experiments. Sampling errors

225 on the feedstock, due to the limited amount of material processed, would have had a

226 significant influence. From our ASR feedstock, it was concluded that a significant source of

227 PAHs was from the plastic and rubber fractions (Table 1).

228 Table 5. Concentrations of PAHs in fine char fraction (at 800 and $1000^{\circ} \mathrm{C}$ ).

\begin{tabular}{lllllll}
\hline Target Compounds & CAS $^{*}$ & $\begin{array}{l}\text { R.T. } \\
(\mathrm{min})\end{array}$ & $\begin{array}{l}\mathrm{Char} \mathrm{800}^{\circ} \mathrm{C} \\
\left(\mathrm{mg} \mathrm{kg}^{-1}\right)\end{array}$ & $\begin{array}{l}\text { Fit } \\
(\%)\end{array}$ & $\begin{array}{l}\mathrm{Char} \mathrm{1000}^{\circ} \mathrm{C} \\
\left(\mathrm{mg} \mathrm{kg}^{-1}\right)\end{array}$ & $\begin{array}{l}\text { Fit } \\
(\%)\end{array}$ \\
\hline
\end{tabular}




\begin{tabular}{lrrrrrl}
\hline Naphthalene & $91-20-3$ & 3.23 & 5010.00 & 99 & 46.60 & 99 \\
Acenaphthylene & $208-96-8$ & 4.36 & 2040.00 & 99 & 91.00 & 99 \\
Acenaphthene & $83-32-9$ & 4.48 & 56.80 & 73 & $<8.00$ & - \\
Fluorene & $86-73-7$ & 4.87 & 192.00 & 99 & 9.63 & 97 \\
Phenanthrene & $85-01-8$ & 5.72 & 3980.00 & 99 & 429.00 & 99 \\
Anthracene & $120-12-7$ & 5.77 & 724.00 & 97 & 101.00 & 98 \\
Fluoranthene & $206-44-0$ & 7.07 & 2470.00 & 89 & 879.00 & 90 \\
Pyrene & $129-00-0$ & 7.36 & 2870.00 & 87 & 1250.00 & 88 \\
Benzo[a]anthracene & $56-55-3$ & 9.05 & 401.00 & 96 & 93.70 & 94 \\
Chrysene & $218-01-9$ & 9.11 & 504.00 & 99 & 124.00 & 97 \\
Benzo[b]fluoranthene & $205-99-2$ & 10.58 & 583.00 & 97 & 268.00 & 90 \\
Benzo[k]fluoranthene & $207-08-9$ & 10.62 & 211.00 & 98 & 70.30 & 90 \\
Benzo[a]pyrene & $50-32-8$ & 11.01 & 609.00 & 97 & 336.00 & 96 \\
Indo[1,2,3-cd]pyrene & $193-39-5$ & 12.38 & 496.00 & 89 & 451.00 & 91 \\
Dibenzo[a,h]anthracene & $53-70-3$ & 12.41 & 42.10 & 85 & 13.10 & 72 \\
Benzo[g,h,i]perylene & $191-24-2$ & 12.68 & 524.00 & 93 & 627.00 & 95 \\
Coronene & $191-07-1$ & 14.88 & 136.00 & 52 & 285.00 & 68 \\
Total (USEPA16) PAHs & & & 20712.90 & & $<4797.33$ & \\
\hline
\end{tabular}

Keys: * Chemical abstracts service registry number; ${ }^{\#}$ Retention time

231 The occurrence of PCBs and BTEX in the fine fraction produced at various pyrolysis

232 temperatures are presented in Table 6. The concentrations of PCBs in the char at $800^{\circ} \mathrm{C}$ were

233 lower compared to the $1000^{\circ} \mathrm{C}$. This was consistent with the observation by (Conesa et al.,

234 2009) that the dioxin and dioxin-like PCBs concentrations increased in pyrolysis products

235 with increasing chlorinated degree and process temperature. The total concentrations of PCBs

236 in char residues produced at $800^{\circ} \mathrm{C}$ and $1000^{\circ} \mathrm{C}$ were $<175.0 \mu \mathrm{g} \mathrm{kg}^{-1}$ and $<508.7 \mu \mathrm{g} \mathrm{kg}^{-1}$,

237 respectively. These concentrations were higher than the value reported by Joung et al. (2007)

238 of $0.869 \mu \mathrm{g} \mathrm{kg}^{-1}$. However, their pyrolysis experiments were carried out using a bench-scale

239 reactor at $600^{\circ} \mathrm{C}$ with no size separations. Therefore, dilution may have occurred from the

240 more inert coarser fraction. This would have similar limitations to those of Buss et al. (2016)

241 and Anzano et al. (2017). The TPHs concentrations of the fine fraction pyrolysed at $1000^{\circ} \mathrm{C}$

242 was significantly lower (a decrease of $67.6 \%$ ) compared to $800^{\circ} \mathrm{C}$ material, with its maximum

243 value of $36200 \mathrm{mg} \mathrm{kg}^{-1}$. It was noted that the quantities of BTEX dropped dramatically at

244 pyrolysis temperature of $1000^{\circ} \mathrm{C}$. In descending order, the BTEX with the highest

245 concentratins (in the char from $800^{\circ} \mathrm{C}$ pyrolysis) were benzene, toluene, xylenes, $\mathrm{m} / \mathrm{p}$ - 
xylenes, $o$-xylene and ethylbenzene. It is interesting to note that thermal treatment of ASR

247 resulted in an increase of organic pollutant emissions (PCBs and BTEX) within the fine

248 fraction, see Table 3. Comparing the values against the waste accepted criteria (Table 4), the

249 coarse chars are non-hazardous and may be safe to be disposed of and/or recycled unlike the

250 fine fraction. This is clearly illustrated in Fig 2 and shows that the fine char does not meet the

251 WAC thresholds. The observed difference between the fine and coarse fractions can be

252 attributed to the residence time within the pyrolyser. The fine fraction had a shorter residence

253 time and therefore a decrease in cracking reactions. This resulted in organic material residing

254 with the char. Similar observation were made by Conesa et al. (2009). Results obtained for

255 TOC (fine fraction) highlighted no significant differences between solid residues of $<25 \%$ wt

256 concentrations at various temperatures, whereas values obtained for LOI revealed a slight

257 increase in concentration in $1000^{\circ} \mathrm{C}$ char residue. Post char treatment may therefore be

258 necessary to meet WAC requirements. However, a potential solution to avoid this would be

259 pretreating the ASR instead. Cossu and Lai, (2013) found that washing of ASR achieved the

260 removal of more than $60 \%$ of the dissolved organic carbon and chemical oxygen demand.

261 It was found that the fine material from $1000^{\circ} \mathrm{C}$ had a similar $\mathrm{pH}$ to that of the original

262 ASR material of 7.2 (Table 4). This implies that there will not be any significant leaching of

263 acidic or basic components of the char residues. This is in contrast to the char from $800^{\circ} \mathrm{C}$

264 which had a higher $\mathrm{pH}$ value of 9.3 , which means that it may lead to potential leaching of

265 basic components from the chars.

266 The difference in properties of the two char fractions may require post screening for

267 acceptance by potential end users as well as to minimise any environmental impacts from

268 final disposal into landfill.

269 Char production from the pyrolysis of ASR in this study was between $30-32 \%$ wt which is

270 similar to that reported in the literature of 33-68\%wt (Harder and Forton, 2007). These

271 quantities may increase with the change of ELV composition to higher proportion of plastics 
272 (Vermeulen et al., 2011). Further investigation of the impact of pre-treatment of the ASR on

273 the fractions would be beneficial as the recycling industry moves towards more post-shredder

274 treatment activity such as sink-float segregation.

275

276 Table 6. Concentrations of PCBs (7 congeners) and BTEX in produced fine char fraction (at 277800 and $\left.1000^{\circ} \mathrm{C}\right)$.

\begin{tabular}{lcc}
\hline Compounds & $\begin{array}{c}\mathbf{C h a r ~ 8 0 0}^{\mathbf{}} \mathbf{C} \\
\left(\boldsymbol{\mu \mathbf { ~ k g } ^ { - 1 } )}\right.\end{array}$ & $\begin{array}{c}\text { Char 1000 } \\
\left(\boldsymbol{\mu \mathbf { ~ k g } ^ { - 1 } )}\right)\end{array}$ \\
\hline PCB28 & $<25.0$ & 59.1 \\
PCB52 & $<25.0$ & 87.2 \\
PCB101 & $<25.0$ & 53.9 \\
PCB118 & $<25.0$ & $<25.0$ \\
PCB153 & $<25.0$ & $<25.0$ \\
PCB138 & $<25.0$ & 210.9 \\
PCB180 & $<25.0$ & 47.6 \\
Benzene & 13100 & 420 \\
Toluene & 1220 & $<25$ \\
Ethylbenzene & 167 & $<25$ \\
Xylenes & 855 & $<75$ \\
$m / p$-xylenes & 679 & $<50$ \\
$o$-xylene & 176 & $<25$ \\
MTBE & $<50$ & $<50$ \\
& & \\
\hline
\end{tabular}




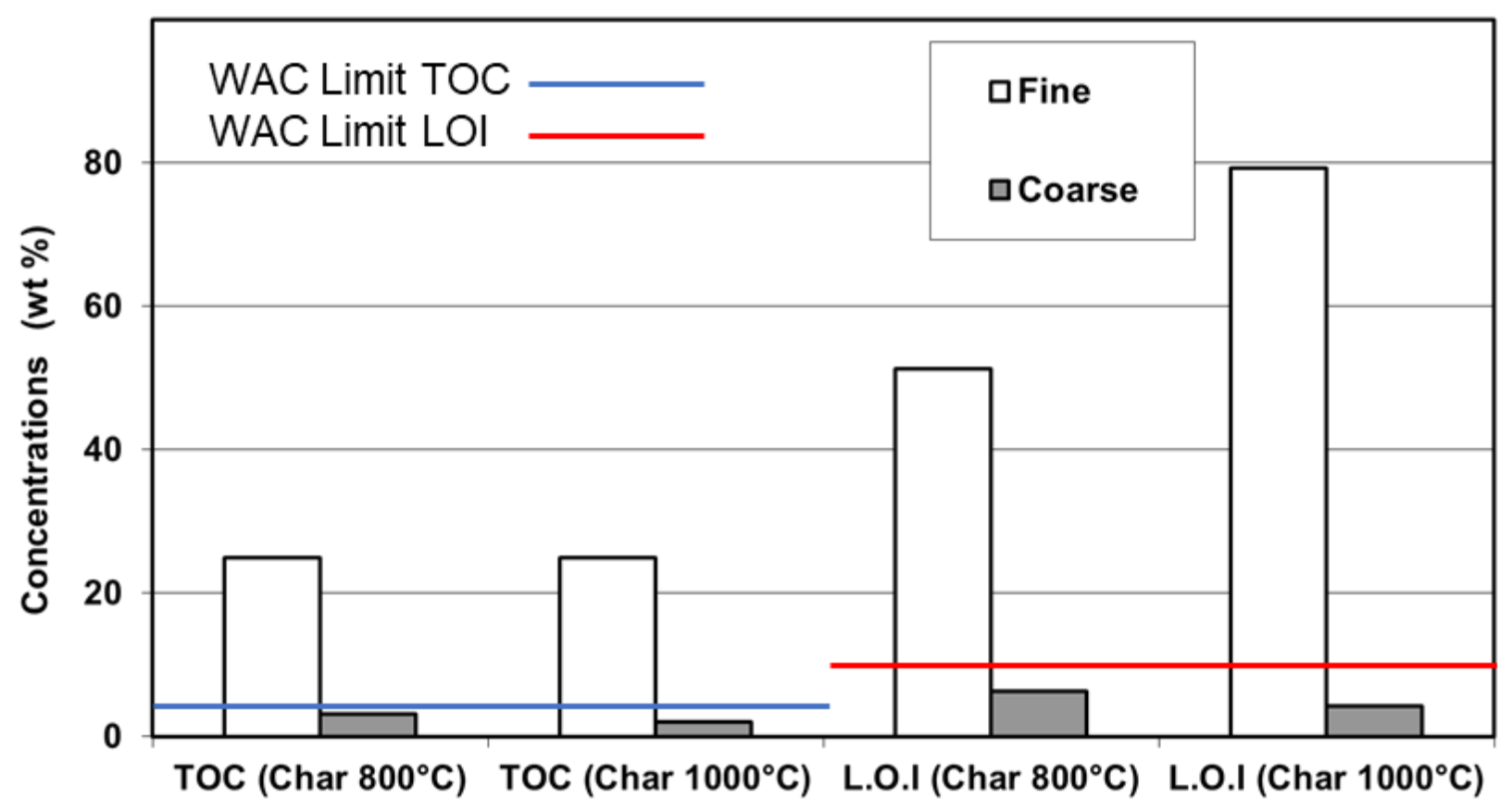

281 Fig 2. Concentration of TOC \& LOI in char samples (at 800 and $1000^{\circ} \mathrm{C}$ ).

\section{Conclusions}

283 The potential future utilisation of ASR as an energy source in advanced pyrolysis processes is

284 currently an attractive option for the shredder industry. The increasing legislative pressures

285 and worsening public perception of plastic materials could prevent the future utilisation of

286 ASR and its by-products. This study has shown some of the potential challenges of thermally

287 treating ASR as a recovery route to meet the ELV directive target.

288 A pilot-scale rotary kiln pyrolyser was used to determine and characterise the organic

289 pollutants from pyrolysis of ASR and untreated ASR. The results revealed that the ASR

290 (obtained from UK shredder plant) can be classified as a non-hazardous waste due to its low

291 contents of hazardous organic substances such as PCBs, PAHs, BTEX and mineral oil.

292 Furthermore, TOC and LOI analysis confirmed that it was an inert waste and complied with

293 the criteria for granular waste acceptance at UK landfills. However, this may not be the case

294 once it has undergone pyrolysis. The char was separated into two fractions fine $<0.1 \mathrm{~mm}$, 
which comprised $20 \%$ wt and $>0.1$ mm coarse which was $80 \%$ wt. Low levels of PAHs,

296 BTEX and TPHs were found in the fine char produced from two pyrolysis temperatures

$2971000^{\circ} \mathrm{C}$ and $800^{\circ} \mathrm{C}$ compared to none in the coarse char. The TOC and LOI analysis of the

298 chars showed that the fines did not meet the WAC criteria unlike the coarse char. This meant

299 that the fine char would have to be dealt with at a specialised landfill site. Whereas the coarse

300 char was classified as an inert material and could be used for secondary uses.

301 The choice of appropriate pyrolysis conditions could be an important factor in obtaining

302 saleable products from the char material. Segregation might be required to make it suitable

303 for further resource recovery processes. The results from the analysis indicated that post-

304 pyrolysis segregation could be required. Therefore, allowing it to be used for secondary

305 markets and contribute towards the ELV 95\% target. Further studies would be required in

306 order to optimise the segregation of char in order to assist in energy and resource recovery.

307 This would ensure that commercially exploitable products were obtained at a reasonable 308 economic cost.

\section{Acknowledgement}

310 The authors gratefully acknowledge Innovate UK's financial support through the Knowledge

311 Transfer Partnership (KTP). As well as the Recycling Lives Limited, Preston, UK for their

312 financial support and access to their facility.

\section{References}

Alonso, J.C., Doce J., Fleischer, G., Geraghty, K., Greif, A., Rodrigo, J., Schmidt, W.P., 2007. Electrical and electronic components in the automotive sector: economic and environmental assessment. Int. J. Life Cycle Assess. 12 (5), 328-335.

Anzano, M., Collina, E., Piccinelli, E., Lasagni, M., 2017. Lab-scale pyrolysis of the automotive shredder residue light fraction and characterisation of tar and solid products. Waste Manag. 64, 263-271. 
BS, British Standards, 1986. BS 6068: Water quality, physical, chemical and biochemical methods - Determination of dissolved oxygen: electrochemical probe method. British Standard Institute.

Buss, W., Graham, M.C., Mackinnon, G., Maŝek, O., 2016. Strategies for producing biochars with minimum PAH contamination. J. Anal. Appl. Pyrolysis 119, 24-30.

Conesa, J.A., Font, R., Fullana, A., Martín-Gullón, I., Aracil, I., Gálvez, A., Moltó, J., Gómez-Rico, M.F., 2009. Comparison between emissions from the pyrolysis and combustion of different wastes. J. Anal. Appl. Pyrolysis 84, 95-102.

Cossu, R., Fiore, S., Lai, T., Luciano, A., Mancini, G., Ruffino, B., Viotti, P., Zanetti, M.C., 2014. Review of Italian experience on automotive shredder residue characterisation and management. Waste Manage. 34, 1752-1762.

Cossu, R., Lai, T. 2013. Washing treatment of automotive shredder residue (ASR). Waste Manage. 33, 1770-1775.

Cossu, R., Lai, T., 2015. Automotive shredded residue (ASR) management: an overview. Waste Manag. 45, 143-151.

Cucchiella, F., Adamo, I. D', Rosa, P., Terzi, S., 2016. Automotive printed circuit boards recycling: an economic analysis. J. Clean. Prod. 121, 130-141.

Davies, G., 2012. Materials for Automobile Bodies, second ed. Elsevier Applied Science Publisher, Amsterdam, pp. 11-13.

Day, M., Cooney, J.D., Shen, Z., 1996. Pyrolysis of automobile shredder residue: an analysis of the products of a commercial screw kiln process. J. Anal. Appl. Pyrolysis 37, 49-67.

Day, M., Shen, Z., Cooney, J.D., 1999. Pyrolysis of auto shredder residues: experiments with a laboratory screw kiln reactor. J. Anal. Appl. Pyrolysis 51, 181-200.

EC, 2000. Directive 2000/53/EC of the European Parliament and the European Council of 18 September 2000 on end-of-life vehicles - commission statements. Off. J. Eur. Comm. L269, 0034-0043, Brussels.

EC, 2002. Directive 2003/33/EC: Council Decision of 19 December 2002 establishing criteria and procedures for the acceptance of waste at landfills pursuant to Article 16 of and Annex II to Directive 1999/31/EC. Off. J. Eur. Comm. L11/27-L11/49, Brussels.

EC, 2004. No. 850/2004 of the European Parliament and the European Council of 29 April 2004 on persistent organic pollutants and amending Directive 79/117/EEC. Off. J. Eur. Un. L158/7-49, EN.

EC, 2019. Report from the commission to the European, the council, the European economic and social committee and the committee of the regions on the implementation of the circular economy action plan. COM/2019/190 final, Brussels, available at http://ec.europa.eu/environment/circulareconomy/pdf/report_implementation_circular_economy_action_plan.pdf Accessed $14^{\text {th }}$ November 2019. 
Eurostat ELV, 2019. Statistics Explained End-of-life, available at

https://ec.europa.eu/eurostat/statistics-explained/index.php?title=End-of-

$\underline{\text { life_vehicle_statistics\&oldid }=461386}$ Accessed $8^{\text {th }}$ January 2020.

Fortuna, F., Cornacchia, G., Mincarini, M., Sharma, V.K., 1997. Pilot-scale experimental pyrolysis plant: mechanical and operational aspects. J. Anal. Appl. Pyrolysis 40-41, 403417.

Galvagno, S., Fortuna, F., Cornacchia, G., Casu, S., Coppola, T., Sharma, V.K., 2001. Pyrolysis process for treatment of automobile shredder residue: preliminary experimental results. Energ. Convers. Manage. 42, 573-586.

GFEA, German Federal Environment Agency, 2012. Polycyclic aromatic hydrocarbons Harmful to the environment, Toxic, Inevitable. November 2012, Press Office, Germany. Available at https://www.bsnc.nl/wp-content/uploads/2015/10/Polycyclic-AromaticHydrocarbons-why-the-ban.pdf Accessed 14 ${ }^{\text {th }}$ November 2019.

Harder, M.K., Forton, O.T., 2007. A critical review of developments in the pyrolysis of automotive shredder residues. J. Anal. Appl. Pyrol. 79 (1), 387-394.

Haydary, J., Susa, D., Gelinger, V., Cacho, F., 2016. Pyrolysis of automobile shredder residue in a laboratory scale screw type reactor. J. Environ. Chem. Eng. 4, 995-972.

Heron, G., Barcelona, M.J., Andersen, M.L., Christensen, T.H., 1997. Determination of nonvolatile organic carbon in aquifer solids after carbonate removal by sulfurous acid. Ground Water 35(1), 6-11.

Joung, H.T., Seo, Y.C., Kim, K.-H., 2007. Distribution of dioxins, furans and dioxin-like PCBs in solid products and generated by pyrolysis and melting of automobile shredder residues. Chemosphere 68, 1636-1641.

Khodier, A., Williams, K.S., Dallison, N., 2017. Pilot-scale thermal treatment of automotive shredder residue: pyrolysis char is a resource or waste, WIT Transaction on Ecology \& the Environment. WIT Press, Energy \& Sustainability 224, 439-450. www.witpress.com,ISSN 1746-448X.

Khodier, A., Williams, K.S., Dallison, N., 2018. Challenges around automotive shredder residue production and disposal. Waste Manag. 73, 566-573.

Mancini, G., Tamma, R., Viotti, P., 2010. Thermal process of fluff: preliminary tests on a full-scale treatment plant. Waste Manag. 30 (8-9), 1670-1682.

Mayyas, M., Pahlevani, F., Handoko, W., Sahajwalla, V., 2016. Preliminary investigation on the thermal conversion of automotive shredder residue into value-added products: graphitic carbon and nano-ceramics. Waste Manage. 50, 173-183.

Morselli, L., Santini, A., Passarini, F., Vassura, I., 2010. Automotive shredder residue (ASR) characterisation for a valuable management. Waste Manag. 30, 2228-2234. 
Notarnicola, M., Cornacchia, G., De Gisi, S., Di Canio, F., Freda, C., Garzone, P., Martino, M., Valerio, V., Villone, A., 2017. Pyrolysis of automotive shredder residue in a bench scale rotary kiln. Waste Manag. 65, 92-103.

Pascal, M.A., Zabik, M.E., Zabik, M.J., Hernandez, R.J, 2005. Uptake of polychlorinated biphenyls (PCBs) from an aqueous medium by polyethylene, polyvinyl chloride, and polystyrene films. J. Agric. Food Chem. 53, 164-169.

Restrepo, E., Løvik, A.N., Wäger, P., Widmer, R., Lonka, R., Müller, D.B., 2017. Stocks, flows and distribution of critical metals in embedded electronics in passenger vehicles. Environ. Sci. Technol. 51(3), 1129-1139.

Ruffino, B., Fiore, S., Zanetti, M.C., 2014. Strategies for the enhancement of automobile shredder residues (ASRs) recycling: results and cost assessment. Waste Manag. 34(1) $148-155$.

Santini, A., Passarini, F., Vassura, I., Serrano, D., Dufour, J., Morselli, L., 2012, Auto shredder residue recycling: mechanical separation and pyrolysis. Waste Manag. 32, 852858.

Schumacher, B.A., 2002. Methods for the determination of total organic carbon (TOC) in soils and sediments. USEPA, Washington, DC, EPA/600/R-02/069 (NTIS PB2003100822).

Selinger, A., Steiner, C., Shin, K., 2003. TwinRec - bridging the gap of car recycling in Europe. Proceedings of the International Automotive Recycling Congress, Geneva, Switzerland, 2003 March 12-14.

Tchobanoglous, G., Theisen, H., Vigil, S., 1993. Integrated Solid Waste Management. McGraw Hill, London, pp. 978.

USDHHS, 1995. US Department of Health and Human Services, Toxicological profile for polycyclic aromatic hydrocarbons (PAHs). ATSDR (Agency for Toxic Substances and Disease Registry), Public Health Service, Atlanta, GA.

USEPA, 2007. EPA 3550C, Ultrasonic Extraction, Office of research and development. Available at: www.epa.gov/sites/production/files/2015-12/documents/3550c.pdf Accessed $14^{\text {th }}$ November 2019

Vermeulen, I., Van Caneghem, J., Block, C., Baeyens, J., Vandecasteele, C., 2011. Automotive shredder residue (ASR): reviewing its production from end-of-life vehicles (ELVs) and its recycling, energy or chemicals valorisation. J. Hazard. Mater. 190 (1), 827.

Viotti, P., Tamma, R., Lombardi, L., Mancini, G., 2010. Thermal process of fluff: results from a full-scale treatment plant experimental campaign, proceeding of Venice 2010, Third International Symposium on Energy from Biomass and Waste, Venice 811/11/2010, pp.11.

Williams, P.T., 2005. Waste Treatment and Disposal, second ed. John Wiley \& Sons Ltd, Chichester, pp. 326-336. 